\title{
BESREDKA'S “ANTIVIRUS” IN RELATION TO FLEMING'S INITIAL VIEWS ON THE NATURE OF PENICILLIN
}

\author{
by \\ MILTON WAINWRIGHT *
}

\begin{abstract}
Alexander Fleming's initial views on the nature and clinical use of penicillin have recently evoked a considerable amount of speculation. ${ }^{1}$ It is clear that Fleming made a number of attempts to use crude penicillin (i.e., filtrates of cultures of Penicillium notatum) on surface wounds during the brief period following his chance discovery of the substance in September $1928 .^{2} \mathrm{He}$ also enlisted the help of a number of students and others in attempts to extract the active ingredient from the crude meat broths on which his penicillin-producing isolate grew. Although Lewis Holt used solvent transfer for the purification of penicillin in $1934,{ }^{3}$ Fleming, with his limited knowledge of chemistry, did not appreciate the importance of this. Harold Raistrick's inability to isolate penicillin in the early 1930s no doubt increased Fleming's sense of the impossibility of the task. ${ }^{4}$ However, it seems that his own experiments had by that time convinced him that penicillin would be quickly inactivated when injected into the bloodstream, and that even if purified, it would be of limited medical use. ${ }^{5}$ Fleming did not discard penicillin altogether, but put it to good use as a component of selective bacterial culture media. There is also anecdotal evidence that he persisted with the view that it might one day find a use in medicine. For example, he is said to have commented to Douglas McLeod on leaving a talk on sulphonamides given by Gerhard Domagk in London in 1935 that in penicillin ${ }^{6}$ he had something much better than Prontosil, but nobody was interested and he was unable to find a chemist who would take the trouble to isolate this substance for him.

My aim in this paper is to show that soon after discovering penicillin, Fleming's thoughts on the nature of penicillin were markedly altered by Besredka's "antivirus",
\end{abstract}

*Milton Wainwright, BSc., Ph.D., Department of Microbiology, University of Sheffield, Sheffield S10 2TN.

\footnotetext{
${ }^{1}$ R. G. Macfarlane, Alexander Fleming, London, Chatto \& Windus, 1984; R. Hare, 'New light on the discovery of penicillin', Med.-leg. Soc. J., 1970, 38: 31-41; M. Wainwright, 'Fleming did discover penicillin', Soc. gen. Microbiol. Q., 1988, 15: 30-1.

${ }^{2}$ A. Fleming, 'On the antibacterial action of cultures of a Penicillium, with special reference to their use in the isolation of B. influenzae', Br. J. exper. Path., 1929, 10: 222-36.

${ }^{3}$ R. Hare, 'New light on the discovery of penicillin', Med. Hist., 1982, 26: 10.

${ }^{4}$ Ibid.

${ }^{5}$ Ibid., pp. 10-18.

${ }^{6}$ E. Bäumler, In search of the magic bullet, London, Thames \& Hudson, 1965, pp. 41-3.
} 


\section{Milton Wainwright}

which was then enjoying something of a vogue. While in 1929 he considered penicillin to be what was later termed an antibiotic, by 1931 he was regarding it as a form of antivirus; it was this change, helped by some discouraging laboratory results, which deflected him from considering penicillin as a potentially important therapeutic agent.

\section{BESREDKA'S “ANTIVIRUS"}

The modern reader might expect that the term "antivirus" would describe a substance capable of inhibiting viruses and thereby possibly curing viral infections. However, the French bacteriologist and immunologist Alexandre Besredka used the term during the 1920 s to describe a novel approach to the treatment of bacterial infections. ${ }^{7}$ Besredka (1870-1940) was born in Odessa, Russia and went to Paris with Elie Metchnikoff as a préparateur. He became Director of the Pasteur Institute on Metchnikoff's death and it was there that he developed his antivirus therapy. This involved applying to wounds or surface infections a filtered broth on which bacteria had grown to exhaustion. This broth was said to contain the antivirus, which was regarded as host specific; that is, staphylococcal, but not for example streptococcal infections, were healed with filtrate of broth on which staphylococci had been grown. The broth filtrate was protein-free, and the antivirus was heat-stable to $100-115^{\circ} \mathrm{C}$. Besredka believed that the beneficial effects of his antivirus resulted from a change in localized immunity in the cells treated with the filtrates, and that any antibacterial effects were purely accidental and secondary. ${ }^{8} \mathrm{He}$ was careful to distance himself from the idea that his broths were necessarily "a bad medium for the culture of their respective bacteria". He therefore objected to the view that the activity of his antivirus was due to the production by bacteria of such antibacterial agents as pyocyanase; nor, in his opinion, were the effects due to staling of bacterial cultures resulting from exhaustion of the growth medium.

Besredka's antivirus therapy was widely used in the 1920s and early 1930s, particularly in continental European countries. Dressings immersed in bacterial filtrates were said to be effective in the treatment of boils, osteomyelitis, and even anthrax. Agar on which bacteria had grown was apparently equally successful. ${ }^{9}$

Antivirus therapy was not without its critics; some concluded that it was the mere act of filtration which conferred the immunizing effects on the broths, and others disputed Besredka's view that his antivirus conferred a specific immunity. Thus Frederick Gay, ${ }^{10}$ among others, while accepting that antivirus therapy was effective, nevertheless concluded that it was non-specific and that even plain bacteriological broth could cause the local proliferation of the macrophages that actually provided the remarkable protective value of antivirus against virulent localized streptococcal infections.

\footnotetext{
${ }^{7}$ A. Besredka, Local immunisation, specific dressings, Baltimore, Williams \& Wilkins, 1927.

${ }^{8}$ Idem, 'Are antiviruses specific?', J. Immun., 1932, 23: 349-60.

${ }^{9}$ H. Jussion, M. Vaucel, and E. Diot, 'Agar vaccines in skin infections', Presse méd., Paris, 1926, 1: 642-5.

${ }^{10}$ F. P. Gay, 'The recent hypothesis of Besredka', in The new knowledge of bacteriology and immunology, ed. E. O. Jordan and I. S. Falk, University of Chicago Press, 1928, pp. 884-90.
} 


\section{Besredka's "antivirus" in relation to Fleming}

WAS ANTIVIRUS THERAPY SUCCESSFUL?

A large number of reports in the medical literature of the 1920 s and early $1930 \mathrm{~s}$ suggest that, although arguments might be raised against the theory of antivirus therapy, in practice it was an extremely effective means of treating bacterial infections, both in animals and man. Ernst Oesterlin, ${ }^{11}$ for example, concluded that the therapeutic benefits of this treatment had been proved to be effective not only in France, but also in Austria and Germany.

An excellent example of a reported cure using antivirus is provided in a report by Alfred Merten and Oesterlin, ${ }^{12}$ who used antivirus in the treatment of malignant oedema caused by Clostridium (i.e., gas gangrene). While working at the pathology laboratory of the Milwaukee Hospital they reported, in 1932, the case of a 12-year-old boy who had fallen from a tree and whose radius of the right arm protruded some two and a half inches. The fracture was operated upon and a splint applied. On the following day his temperature rose to $103^{\circ} \mathrm{F}$ and on the third day the arm was reported as swollen and emitting an offensive odour. Some four weeks after the accident, and despite extensive conventional treatment, the arm was still swollen and gas bubbles continued to issue from the wound. On the twenty-eighth day Oesterlin applied the antivirus to the wound, using a soaked dressing. The antivirus was prepared by inoculating a broth culture with Clostridium in a flask, overlaying it with liquid paraffin and incubating it for eight days. The broth was then filtered and heated to $100^{\circ} \mathrm{C}$ for five minutes.

Within two hours of the application of the antivirus to the wound, the boy's temperature rose to $101.4^{\circ} \mathrm{F}$. It fell to normal within the next forty-eight hours. On the eighth day of the treatment, the wound showed definite signs of healing and no gas evolution was apparent. The young boy was allowed home seven weeks after the accident. Merten and Oesterlin ended their report by stating that, "while the anatomic result in this case is not all that could be desired, the boy has a functional hand, and not an artificial appliance", and they concluded that antivirus treatment had been the major factor in saving the hand.

Antivirus was even produced on a commercial scale. Allen and Hanbury, Vere Street, London, for example, advertised an antivirus in the Medical Annual of 1926, ${ }^{13}$ advising customers that after a bacteriological examination, antivirus could be prepared for local application to infections of the skin, genito-urinary passages, nose, mouth, and throat. The same year the Leeds firm of Reynolds and Branson advertised, in the same journal, a staphylococcal acne bacillus filtrate (not directly referred to as an antivirus) which they claimed could be successfully applied to the skin for the treatment of acne and some forms of eczema. ${ }^{14}$ Finally Roberts and Co. of New Bond Street, London advertised in 1930 a substance called "Antivirus Bi-Ro", prepared by a Paris-based company, La Biothérapie. ${ }^{15}$ This product was a mixed streptococcal-staphylococcal antivirus, recommended for application to burns

${ }^{11}$ E. J. Oesterlin, 'Experimental studies with pyocyaneus filtrates', J. Immun., 1929, 16: 359-67.

12 A. N. E. Merten and E. J. Oesterlin, 'Antivirus treatment of malignant oedema infections', Ann. Surg., 1932, 95: 101-5.

13 [Anon.], 'Antivirus', Med. Ann., 1926, p. 532.

14 [Anon.], 'Staphylococcus acne bacillus filtrate', ibid., p. 536.

15 [Anon.], 'Antivirus Bi-ro', ibid., 1930, p. 570. 


\section{Milton Wainwright}

or wounds. Again, purchasers had to specify the type of bacteria which had caused the infection they hoped to treat. By the early 1930s, then, there was a small, if growing, commercial supply of antivirus. ${ }^{16}$

BESREDKA'S ANTIVIRUS AND FLEMING'S INITIAL VIEWS ON PENICILLIN

On 15 May 1929 a paper giving details of Besredka's ideas about antivirus was communicated to the Royal Society of Medicine by Dr Broughton Alcock. ${ }^{17}$ Besredka was prevented by a bad cold from giving the paper in person, which was unfortunate because it came in for considerable criticism that would have been effectively addressed only by Besredka. The paper was the subject of editorials in both the British Medical Journal ${ }^{18}$ and the Lancet,${ }^{19}$ which, while recognizing the potential importance of the antivirus therapy, nevertheless maintained the critical atmosphere which surrounded Besredka's views in England.

The British Medical Journal editorial elicited some response from readers on the subject of antivirus. A. G. Buchanan from Johannesburg testified to the usefulness of bacterial filtrates in fighting infections, but concluded that Besredka's idea of the involvement of a localized immunity was unhelpful. ${ }^{20}$ R. F. Hunwick ${ }^{21}$ also commented on how useful antivirus therapy could be, but regarded its success as the result of the filtrates' ability to inhibit the growth of pathogenic bacteria. His views on the action of antivirus were therefore closer to the modern idea of antibiosis than was Besredka's concept of localized immunity.

Fleming attended this meeting in London, and his comments on antivirus were recorded at length in the Proceedings of the Royal Society of Medicine. ${ }^{22} \mathrm{He}$ had discovered penicillin only nine months before and had already submitted his famous first paper on penicillin, which arrived on the desk of the editor of the British Journal of Experimental Pathology and Bacteriology five days before the meeting, on 10 May. ${ }^{23}$

Fleming's initial response to the Besredka paper was on the whole critical and, like other contributors to the discussion, he found it difficult to know exactly what Besredka meant by "antivirus". A number of Fleming's comments are worth quoting in full, especially since he referred to penicillin and in comparing its properties with those of antivirus gives us a unique insight into his view of the nature of penicillin soon after its discovery.

The first relevant comment is,

In this paper he [Besredka] relies in the main on clinical reports of cases treated by various physicians, male and female, and not under his own supervision; favourable clinical reports can easily be obtained for almost any method of treatment.

${ }_{17}^{16}$ [Anon.], 'Gonococcal antivirus', ibid., pp. 262-3.

17 A. Besredka, 'Antivirus therapy in infectious diseases', Proc. R. Soc. Med., 1929, 22: 1579-98.

18 [Anon.], 'Antivirus therapy', Br. Med. J., 1929, i: 955-6.

19 [Anon.], 'The antivirus of Besredka', Lancet, 1929, i: 1157.

${ }^{20} \mathrm{G}$. Buchanan, 'Bacterial filtrates or antivirus therapy', letter, Br. Med. J., 1929, ii: 324.

${ }^{21}$ R. F. Hunwick, 'Antivirus therapy', letter, ibid., i: 1100.

22 Besredka, op. cit., note 17 above.

${ }^{23}$ Fleming, op. cit., note 2 above. 


\title{
Besredka's "antivirus" in relation to Fleming
}

This statement is particularly interesting because at that time Fleming was probably involved in attempts to use penicillin to treat surface infections and wounds. Even had he achieved occasional clinical successes with crude penicillin, he would not necessarily have laid great stress upon these results since they would be no more nor less than could be obtained "for almost any method of treatment". This, no doubt correct, attitude to the occasional successful outcome of a novel therapy may explain why both Fleming and Cecil G. Paine failed to continue their therapeutic studies on crude penicillin, which in hindsight would appear to have been promising. ${ }^{24}$

Fleming then referred to penicillin.

\begin{abstract}
Recently I have been making some observations on somewhat similar lines. I found that when a particular mould had been grown in broth for a week or ten days, the filtrate of the culture had remarkable inhibitory properties on the growth of some microbes, especially the pyogenic cocci. This filtrate, like Besredka's antivirus, consists of nutrient broth, except that instead of being exhausted by a bacterium it has supported the growth of a mould for some time (not to exhaustion).
\end{abstract}

In this statement Fleming successfully summarized his recent work on penicillin, which he contrasted with antivirus as a broth obtained by growing a culture, but not to exhaustion. He had earlier pointed out that the inhibitory power of such exhausted broths had frequently been demonstrated, a phenomenon which he said could be due "either to the exhaustion of the broth in regard to some foodstuff necessary to the growth of the particular microbe, or to the accumulation of waste products which inhibited further growth".

Fleming continued his reference to penicillin,

I have applied this filtrate to a number of septic wounds (abscesses, burns, ulcers etc.), and so far the results are certainly not inferior to the cases cited by Besredka. One patient treated during the last ten days is interesting. A woman had indolent ulcers in various parts of the body. These ulcers had existed for over two months and showed little signs of healing. The infecting agents in each case were staphylococci and streptococci. The filtrate was applied in compresses every four hours, and in three or four days the aspect of the ulcers completely changed; they became healthy looking, granulations formed and healing commenced and is progressing rapidly.

Here we have the first description of a penicillin cure, which would have been achieved by Fleming around 19 May 1929. It is, however, as yet unsubstantiated by case notes (which may exist at St Mary's Hospital, Paddington). He almost certainly worked with Arthur Dickson Wright, who referred to his collaboration with Fleming on the therapeutic applications of penicillin in $1945 .^{25}$ That they worked together was also stated by Almroth Wright in a discussion of a paper read by Dickson Wright to the Medical Society of London, 1931. ${ }^{26}$ This paper dealt with the treatment of indolent ulcers of the leg, on which Dickson Wright was a recognized

\footnotetext{
${ }^{24}$ M. Wainwright and H. T. Swan, 'C. G. Paine and the earliest surviving clinical records of penicillin therapy', Med. Hist., 1986, 30: 42-56.

${ }_{25}$ A. Fleming, 'The uses and limitations of penicillin', Trans. Med. Soc. Lond., 1945, 64: 147.

${ }^{26}$ A. Dickson Wright, 'The treatment of indolent ulcer of the leg', ibid., 1931, 54: 237-51.
} 


\section{Milton Wainwright}

authority. Despite its considerable length, it gives no reference to penicillin in the treatment of indolent ulcers. Either the penicillin work was less promising than Fleming suggested or, perhaps, Dickson Wright considered it to be too preliminary to be included in this review.

In concluding his comparison of penicillin and Besredka's antivirus, Fleming wrote,

Here I would point out that in the mould filtrate there was no question of specific immunity; there was nothing in the preparation specific to staphylococci or streptococci, but it was simply broth in which a mould had been grown. I therefore venture to suggest that the improvement in many of the cases sited by Besredka need not have any relation to a specific immunizatory process, and that the term "local immunity" is the wrong one to apply.

In this final statement Fleming clearly distanced himself from the view that penicillin's curative effect on indolent ulcers, for example, was due to the induction of a localized immunity. One is therefore left with the clear impression that Fleming considered that penicillin was effective by virtue of its ability to kill the pathogenic bacteria involved, although this is not stated outright.

Although Fleming clearly contrasted penicillin and Besredka's antivirus, he also noted a number of similarities. Anyone who took an interest in penicillin could, from that point on, have dismissed it as a variant of antivirus, a concept which had come in for considerable criticism, bordering on downright disbelief.

It is clear that in May 1929 Fleming saw penicillin as a possible therapeutic agent, although one limited to external use. Any successes he achieved with crude penicillin he thought were due to the antibacterial activity of the filtrate, rather than to the induction of a localized immunity. So, at this time, Fleming seems to have regarded penicillin as what we would now term an antibiotic. However, in 1931, he dismissed the idea that a substance would be found which would act as a "universal germicide" when put into the bloodstream. ${ }^{27}$ Fleming's pessimism about finding a universal germicide which would be effective when injected into the bloodstream was by no means unusual in medical circles during the 1930s. B. S. Levine, ${ }^{28}$ for example, probably gave the standard view on this subject in a paper published in the Journal of Laboratory and Clinical Medicine (1930-31), when he stated that, "The intravenous method of therapeutic application is much more difficult to approach [than surface application]. In fact it has been found that no matter what the outcome of in vitro experiments the intravenous method may result in failure." It was not until the successful intravenous use of Prontosil in the mid-1930s that medical opinion on this point underwent a radical change.

While Fleming's initial view of penicillin seems to have approached the modern concept of an antibiotic, he had apparently undergone a complete change of mind by the time his second penicillin paper appeared in the Journal of Pathology and

\footnotetext{
${ }^{27}$ [Anon.], 'Intravenous use of germicides', Lancet, 1931, i: 349-51.

${ }^{28}$ B. S. Levine, 'Testing the efficiency of bactericidal and bacteriostatic reagents for use in specific chemotherapeusis', J. Lab. clin. Med., 1930-1, 16: 52-8.
} 


\section{Besredka's "antivirus" in relation to Fleming}

Bacteriology in $1931 .^{29}$ In it, he again made a fleeting reference to the use of crude penicillin as a dressing for indolent septic wounds, and then he wrote, "It is unlikely that it [penicillin] acts by killing bacteria directly." He continued,

Gratia (1923) and others have shown that when compresses of broth are applied to the skin there is an aggregation of phagocytic cells in the deeper layers and he has thus explained the rationale of Besredka's antivirus treatment. Penicillin might then act in the same way as antivirus but is superior to ordinary [my italics] antivirus in that it inhibits the growth of not only one but all the pyogenic cocci.

No longer did Fleming regard penicillin as an antibiotic, but as a definite variant of Besredka's antivirus which does not act by killing bacteria directly, but "by promoting the aggregation of phagocytes which then deal with the pathogenic bacteria".

He concluded this section of his second paper with an explanation for his failure to pursue his clinical studies with penicillin: "The practical difficulty in the use of penicillin for dressings of septic wounds is the amount of trouble necessary for its preparation and the difficulty of maintaining its potency for more than a few weeks."

Fleming did not abandon the idea that penicillin might be used in medicine. Further attempts were made during the early 1930s to purify penicillin, both by Raistrick's team and at St Mary's. Although Fleming may have been deflected by Besredka's antivirus from the true nature of penicillin, this should not detract from the fact that he discovered the substance and tried to use it in medicine.

By the time Howard Florey and Ernst Chain came to look at penicillin in 1938, the whole climate of medical opinion had been altered by the appearance of the sulphonamides, and Besredka's antivirus, if not discredited, had become an anachronism.

Many of the supposed antibacterial agents developed in the 1930s have now fallen into oblivion. Some have recently been re-evaluated, among them bacteriotherapy, maggot therapy, and bacteriophage therapy. Perhaps it is an opportune moment, then, to re-evaluate the effectiveness of Besredka's antivirus, for which many hundreds of cures were claimed.

${ }^{29}$ A. Fleming, 'On specific antibacterial properties of penicillin and potassium tellurite', J. Path. Bact., 1932, 35: 831-42. 